CZASOPISMO INŻYNIERII LĄDOWEJ, ŚRODOWISKA I ARCHITEKTURY JOURNAL OF CIVIL ENGINEERING, ENVIRONMENT AND ARCHITECTURE

JCEEA, t. XXXIII, z. 63 (3/16), lipiec-wrzesień 2016, s. 563-570

Agata ZDYB
Piotr LICHOGRAJ $^{2}$

\title{
ZNACZENIE WARUNKÓW WIATROWYCH W FUNKCJONOWANIU MODUŁÓW FOTOWOLTAICZNYCH
}

\begin{abstract}
Wyznaczane w warunkach standardowych dane dotyczące parametrów pracy modułów fotowoltaicznych dostarczane przez producentów nie pokrywają się z faktycznymi rezultatami otrzymywanymi podczas działania modułów w realnych warunkach. $\mathrm{Z}$ tego względu istotne jest testowanie modułów w zewnętrznych instalacjach oraz symulowanie pracy modułów z uwzględnieniem wpływu czynników zewnętrznych takich jak: natężenie promieniowania słonecznego, temperatura i prędkość wiatru. Sprawność ogniw fotowoltaicznych, podobnie jak innych urządzeń półprzewodnikowych, zależy w znacznym stopniu od temperatury, w której ogniwo działa. Zwiększenie temperatury powoduje wzrost energii elektronów i zwężenie przerwy energetycznej półprzewodnika. W przebiegu charakterystyki $I-V$ ogniwa jest to widoczne jako spadek wartości napięcia obwodu otwartego i niewielki wzrost wartości natężenia prądu zwarcia. W praktyce na temperaturę ogniwa wpływ ma zarówno moc padającego promieniowania słonecznego jak i temperatura zewnętrzna oraz siła wiatru. W wielu ośrodkach na świecie prowadzone są eksperymentalne obserwacje pracy modułów fotowoltaicznych wykonanych $\mathrm{w}$ różnych technologiach i zainstalowanych w różnych warunkach klimatycznych. Przedmiotem analiz przeprowadzonych w przedstawionej pracy jest znaczenie czynników zewnętrznych, w szczególności wiatru w działaniu cienkowarstwowych ogniw fotowoltaicznych wykonanych z amorficznego krzemu. Obliczenia oparte na teoretycznym modelu wskazują na chłodzącą rolę wiatru o prędkościach do ok. $10 \mathrm{~m} / \mathrm{s}$ oraz związane z tym podwyższenie sprawności modułów. Dalszy wzrost prędkości wiatru nie ma istotnego wpływu na wartości sprawności. Moduły z krzemu amorficznego cechuje dobra odporność na wahania temperatury, mogą one więc być stosowane w klimacie o wyraźnie odróżniających się porach roku np. w Polsce.
\end{abstract}

Słowa kluczowe: fotowoltaika, ogniwa amorficzne, sprawność, temperatura ogniw

\footnotetext{
${ }^{1}$ Autor do korespondencji / corresponding author: Agata Zdyb, Wydział Inżynierii Środowiska, Politechnika Lubelska, ul. Nadbystrzycka 40B, 20-618 Lublin, tel: (+081) 538 4747, a.zdyb@pollub.pl

${ }^{2}$ Piotr Lichograj, Państwowa Szkoła Wyższa im. Papieża Jana Pawła II w Białej Podlaskiej, Biała Podlaska 21-500, ul. Sidorska 95/97, p.lichograj@gmail.com
} 


\section{Wprowadzenie}

Prace prowadzone od wielu lat w licznych ośrodkach naukowych doprowadziły do dużego zróżnicowania technologii fotowoltaicznych. Obecnie wyróżnić można więc cztery generacje ogniw słonecznych, które przedstawione są w Tabeli 1. Spośród wielu typów wytwarzanych ogniw słonecznych na rynku fotowoltaiki nadal dominują zaliczane do I generacji tradycyjne ogniwa wykonane z monokrystalicznego, polikrystalicznego lub multikrystalicznego krzemu, których udział w zastosowaniach wynosi ok. $80 \%$. Drugie miejsce pod względem rozpowszechnienia na rynku fotowoltaiki, czyli ok. $20 \%$ rynku należy do ogniw cienkowarstwowych, stanowiących II generację.

Tabela 1. Cztery generacje ogniw słonecznych

Table 1. Four generations of solar cells

\begin{tabular}{|c|c|}
\hline Ogniwa słoneczne & Rodzaj materiału \\
\hline I generacja & $\begin{array}{l}\text { mono-Si, multi-Si }(1 \mathrm{~mm} \text { do } 10 \mathrm{~cm}) \text {, } \\
\text { poli-Si }(1 \mathrm{~mm} \text { do } 1 \mathrm{~mm})\end{array}$ \\
\hline II generacja & $\begin{array}{l}\text { a-Si:H } \\
\text { CdS/CdTe } \\
\text { CuInSe }, \text { CuInS (CIS), Cu(InGa) })_{3} \mathrm{Se}_{2} \text { (CIGS) } \\
\text { GaAs, GaN, Ge, GaInPAs }\end{array}$ \\
\hline III generacja & $\begin{array}{l}\text { ogniwa barwnikowe (DSSC) } \\
\text { ogniwa organiczne (OPV) }\end{array}$ \\
\hline IV generacja & $\begin{array}{l}\text { ogniwa sensybilizowane nanocząstkami } \\
\text { (QDSSC) }\end{array}$ \\
\hline
\end{tabular}

Rodzaj zastosowanej technologii fotowoltaicznej ma zasadniczy wpływ na ilość energii elektrycznej produkowanej przez dany moduł fotowotaiczny. Istotne znaczenie mają też warunki zewnętrzne, w których moduły pracują. Dla modułu wykonanego w konkretnej technologii znane $\mathrm{z}$ danych od producenta są takie parametry jak: natężenie prądu zwarcia, napięcie obwodu otwartego, maksymalna moc oraz sprawność. Wartości tych parametrów wyznaczane są w tzw. warunkach standardowych (STC - Standard Test Conditions), czyli przy oświetleniu $1000 \mathrm{~W} / \mathrm{m}^{2}$, AM 1,5G (AM - Air Mass) i temperaturze $25^{\circ} \mathrm{C}$. Takie warunki pracy rzadko występują podczas działania modułów zainstalowanych w realnych warunkach zewnętrznych. W rzeczywistych zastosowaniach moduły poddane są działaniu licznych zmiennych czynników pogodowych i sprawność ich również ulega zmianom. Najważniejszym i często jedynym branym pod uwagę czynnikiem zewnętrznym wpływającym na pracę modułów jest nasłonecznienie $w$ danej lokalizacji. Parametr ten ma kluczowe znaczenie ponieważ wiąże się on z liczbą fotonów promieniowania słonecznego, które mogą zostać zaabsorbowane przez ogniwo i wziąć udział w fotowoltaicznej konwersji ener- 
gii. W Polsce nasłonecznienie wynosi $950-1250 \mathrm{kWh} / \mathrm{m}^{2}$ w ciągu roku w zależności od lokalizacji i różni się ok. 4 razy między półroczem zimowym i letnim. Wartości nasłonecznienia na kuli ziemskiej zależą głównie od szerokości geograficznej, ale znaczenie ma też ukształtowanie terenu, bliskość zbiorników wodnych i inne warunki charakterystyczne $w$ danym położeniu geograficznym.

Kolejnym parametrem wpływającym na pracę instalacji fotowoltaicznych, podobnie jak innych urządzeń wykorzystujących półprzewodniki jest temperatura [1-3]. Najważniejsze własności półprzewodników zmieniające się ze wzrostem temperatury to przerwa energetyczna, której wartość maleje i czas życia nośników mniejszościowych który zwiększa się. Wzrost temperatury powoduje także osłabienie zdolności złącza p-n do separacji powstałych w zjawisku fotowoltaicznym nośników prądu poprzez obniżenie bariery potencjału na złączu. Procesy te mogą powodować obniżenie mocy krzemowych modułów do $23 \%$ potencjalnej mocy wyjściowej przy wzroście temperatury o $35^{\circ} \mathrm{C}$.

Oprócz nasłonecznienia i temperatury, do czynników wpływających na jakość pracy modułów fotowoltaicznych w warunkach zewnętrznych zaliczyć można prędkość wiatru, czystość powierzchni modułów i wilgotność. Prędkość wiatru, choć często jest pomijana w rozważaniach dotyczących modułów, odgrywa istotną rolę, jak wskazują analizy pracy instalacji w różnych warunkach klimatycznych [4].

Jednym z półprzewodników stosowanych w ogniwach słonecznych w postaci cienkich warstw jest krzem amorficzny. Stanowi on bardzo dobry materiał do zastosowań w ogniwach ze względu na wartość przerwy energetycznej, która wynosi $1,7 \mathrm{eV}$ i pozwala na absorpcję szerokiego zakresu promieniowania słonecznego. Jednak z powodu występowania efektu Staeblera-Wronskiego, który powoduje spadek wydajności ogniw podczas ich początkowej ekspozycji na światło oraz dość słabej trwałości nie zdobyły one dużej popularności na rynku fotowoltaiki. Stosunkowo niska cena krzemu amorficznego zachęca mimo to do tworzenia ogniw, które mają zmodyfikowaną strukturę np. typu p-i-n, HIT (Heterojunction with Intrinsic Thin Layer) lub z warstwami ELO (Epitaxial Lateral Overgrowth) [5-7].

Ogniwa wykorzystujące krzem amorficzny stanowią ciekawy obiekt w rozważaniach na temat wpływu warunków zewnętrznych, w szczególności temperatury i wiatru na pracę ogniw ponieważ charakteryzuje je wartość współczynnika temperaturowego wynosząca $0.2 \% /{ }^{\circ} \mathrm{C}$. Jest to wartość mniejsza niż dla krzemu krystalicznego i najniższa spośród innych materiałów stosowanych w ogniwach cienkowarstwowych.

Przedstawiona praca poświęcona jest badaniom symulacyjnym opartym na wykorzystaniu matematycznego modelu opisującego wpływ temperatury, natężenia promieniowania słonecznego i prędkości wiatru na sprawność amorficznych krzemowych ogniw słonecznych. 


\section{Opis metod badawczych}

W prowadzonych pracach wykorzystany był model matematyczny opisujący zależność temperatury modułu fotowoltaicznego i jego sprawności od natężenia promieniowania słonecznego, prędkości wiatru i temperatury otoczenia. Dokładność zastosowanego modelu jest potwierdzona przez wyniki analiz eksperymentalnych. Przy użyciu tego modelu w odniesieniu do technologii a-Si pierwiastek średniego błędu kwadratowego (RMSE - Root Mean Squared Error) wynosi 1,7, a wartość współczynnika determinacji równa jest 0,98 [4]. Obliczenia wykonane zostały przy zastosowaniu oprogramowania MatLab.

\section{Wyniki badań $\mathrm{i}$ ich analiza}

Jednym z najważniejszych parametrów charakteryzujących ogniwa słoneczne jest ich sprawność. Wielkość ta podobnie jak natężenie prądu zwarcia $\left(I_{S C}\right)$ i napięcie obwodu otwartego $\left(V_{O C}\right)$ może być wyznaczona na podstawie charakterystyki prądowo napięciowej ogniwa, co przedstawia poniższy wzór [8]:

$$
\eta=\frac{P_{M P}}{P_{\text {in }}}=\frac{F F V_{O C} I_{S C}}{P_{\text {in }}}
$$

gdzie: $P_{i n}-$ moc promieniowania padającego.

W powyższym wyrażeniu występuje także inny parametr cechujący ogniwa słoneczne - współczynnik wypełnienia ( $F F$ - Fill Factor), który wyznaczyć można znając natężenie $I_{M P}$ oraz napięcie $V_{M P}$ w punkcie mocy maksymalnej $P_{M P}[8]$ :

$$
F F=\frac{P_{M P}}{V_{O C} I_{S C}}=\frac{V_{M P} I_{M P}}{V_{O C} I_{S C}}
$$

W celu przeanalizowania wpływu wymienionych czynników na temperaturę, a następnie sprawność ogniwa wykorzystane zostały zależności teoretyczne. Spośród licznych formuł opisujących temperaturę ogniw fotowoltaicznych wybrany został model opisany poniższym wzorem [4]:

$$
T_{c}=T_{a}+\frac{I}{U_{0}+U_{1} v_{w}}
$$

gdzie: $T_{a}$ - temperatura zewnętrzna,

$I$ - natężenie promieniowania słonecznego,

$v_{w}$ - prędkość wiatru,

$U_{0}, U_{1}$ - współczynniki zależne od transportu ciepła na drodze konwekcji, promieniowania i przewodnictwa w module wykonanym w danej technologii. 
Przestawiona zależność wykazuje w literaturze dobrą zgodność obliczeń $\mathrm{z}$ danymi eksperymentalnymi uzyskanymi dla ogniw wykonanych $\mathrm{z}$ amorficznego krzemu. Przyjęte do obliczeń wartości współczynników związanych z przekazem ciepła dla a-Si wynoszą: $U_{0}=25,73 \mathrm{~W} /{ }^{\circ} \mathrm{Cm}^{2}$ i $U_{I}=10,67 \mathrm{Ws} /{ }^{\circ} \mathrm{Cm}^{3}$.

Sprawność ogniw a- Si przedstawiona na Rys. 1 i 2 wyznaczona została na podstawie następującej zależności, uwzględniającej temperaturę $T c$ ogniwa, na którą wpływ ma prędkość wiatru [1]:

$$
\eta=\eta_{S T C}\left[1-\beta_{S T C}\left(T_{C}-T_{S T C}\right)\right],
$$

gdzie: $\eta_{S T C}, \beta_{S T C}, T_{S T C}-$ sprawność, współczynnik temperaturowy i temperatura pracy modułu w warunkach standardowych.

Pozostałe przyjęte do obliczeń parametry, występujące w równaniu 3 i 4 przedstawione są $\mathrm{w}$ Tabeli 2 .

Tabela 2. Wartości parametrów przyjętych w modelu

Table 2. The values of model parameters

\begin{tabular}{|c|c|c|c|c|}
\hline Parametr & $\begin{array}{c}\text { Półrocze } \\
\text { letnie }\end{array}$ & $\begin{array}{c}\text { Półrocze } \\
\text { zimowe }\end{array}$ & $\begin{array}{c}\text { Wartośćc } \\
\text { maks. }\end{array}$ & $\begin{array}{c}\text { Wartość } \\
\text { min. }\end{array}$ \\
\hline$T_{a}\left({ }^{\circ} \mathrm{C}\right)$ & 14,4 & 1,15 & 30 & -10 \\
\hline$I\left(\mathrm{~W} / \mathrm{m}^{2}\right)$ & 600 & 300 & 1000 & 100 \\
\hline$\eta_{S T C}(\%)$ & \multicolumn{5}{|c|}{6,0} \\
\hline$\beta_{S T C}\left(\% /{ }^{\circ} \mathrm{C}\right)$ & \multicolumn{5}{|c|}{0,19} \\
\hline$T_{S T C}\left({ }^{\circ} \mathrm{C}\right)$ & \multicolumn{5}{|c|}{25} \\
\hline
\end{tabular}

Rys. 1 przedstawia zmiany sprawności ogniw a-Si związane z obniżaniem ich temperatury przez wiatr. Widoczny wpływ wiatru jest znacząco większy w przypadku skrajnie wysokiej wartości temperatury otoczenia i natężenia promieniowania słonecznego.

Rezultaty obliczeń przeprowadzonych dla średnich wartości temperatury zewnętrznej i natężenia promieniowania słonecznego wskazują na większą rolę wiatru w półroczu letnim. 


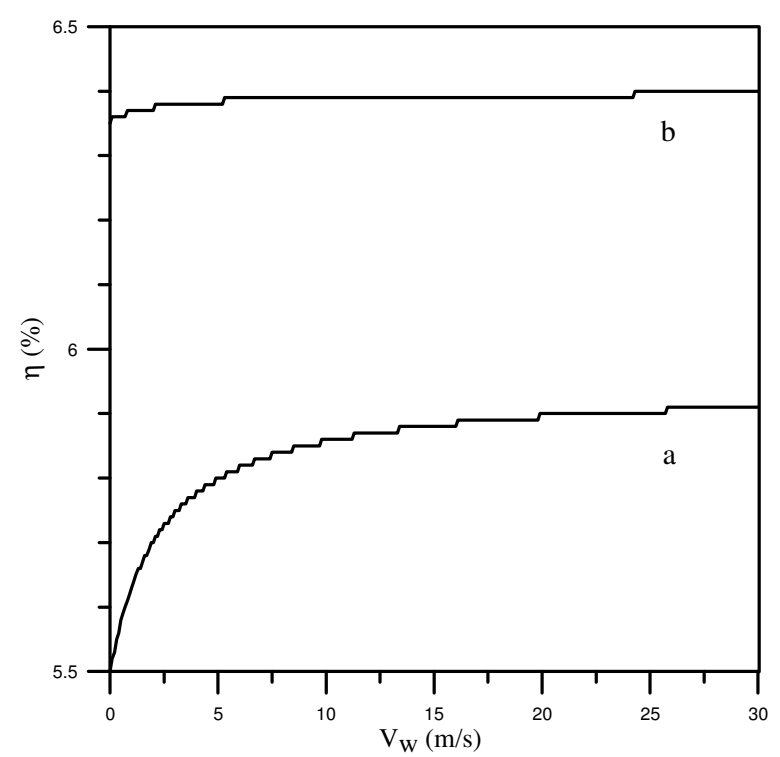

Rys. 1. Zależność sprawności ogniw słonecznych z amorficznego krzemu od prędkości wiatru w warunkach skrajnych; a - maksymalne wartości $T_{a}$ oraz $I, \mathrm{~b}$ - wartości minimalne $T_{a}$ oraz $I$

Fig. 1. The dependency of a-Si solar cells efficiency on the wind speed in extreme conditions; a - maximum values of $T_{a}$ and $I, \mathrm{~b}-$ minimum values of $T_{a}$ and $I$

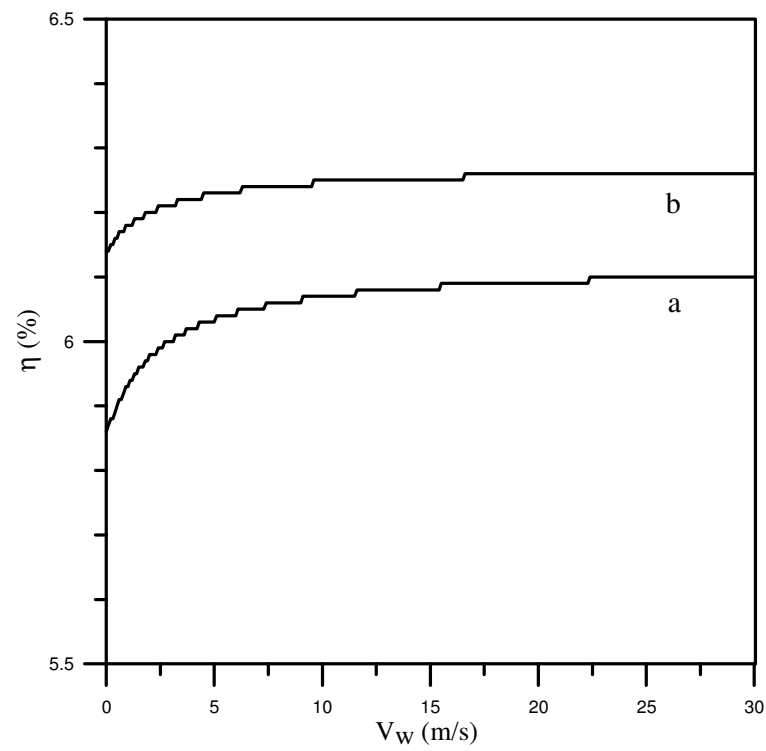

Rys. 2. Zależność sprawności ogniw słonecznych z amorficznego krzemu od prędkości wiatru w przeciętnych warunkach; $\mathrm{a}$ - półrocze letnie, $\mathrm{b}$ - półrocze zimowe

Fig. 2. The dependency of a-Si solar cells efficiency on the wind speed in average conditions; $a$ - warm part of the year, $b$ - cold part of the year 


\section{Wnioski}

Analizy symulacyjne przeprowadzone w pracy wykazują dużą odporność modułów wykorzystujących krzem amorficzny na zmiany temperatury. Materiał ten ma dwukrotnie mniejszy współczynnik temperaturowy niż krzem monokrystaliczny lub polikrystaliczny. Z tego względu, zgodnie z przeprowadzonymi obliczeniami, chłodząca rola wiatru skutkuje niewielką poprawą wydajności.

$\mathrm{Z}$ punktu widzenia inwestora zakupującego moduły należy kierować się nie tylko ich ceną, ale także zwrócić uwagę na to w jakiej technologii są one wykonane i w jakich warunkach klimatycznych będą one zainstalowane. Cienkowarstwowe moduły a-Si, ze względu na stosunkowo dużą odporność na zmiany temperatury mogą być $\mathrm{z}$ powodzeniem stosowane $\mathrm{w}$ klimacie charakteryzującym się znacznymi wahaniami temperatury i prędkości wiatru, np. w Polsce. Projektowanie instalacji fotowoltaicznej powinno być poprzedzone teoretyczną analizą pracy danego typu modułów w wybranej lokalizacji.

\section{Literatura}

[1] Skoplaki E., Palyvos J.A.: On the temperature dependence of photovoltaic module electrical performance: A review of efficiency/power correlations, Solar Energy, 83, 2009, pp. 614-624.

[2] Olchowik J.M., Jóźwik I., Szymczuk D., Zabielski K., Mucha J., Tomaszewski R., Banaś J., Olchowik S., Adamczyk J., Cieplak T., Zdyb A: Analysis of solar cells efficiency in hybrid solar system under conditions of south-easterly Poland: Proc. of $19^{\text {th }}$ European Photovoltaic Solar Energy Conference, 7-11 June 2004, Paris, France, pp. 3294-3296.

[3] Olchowik J.M., Gułkowski S., Cieslak K., Jóźwik I., Banaś J., Olchowik S., Zdyb A., Szymczuk D., Adamczyk J., Tomaszewski R., Zabielski K., Mucha J., Cieplak T.: Comparative study of the solar modules performance in the hybrid system in southeasterly Poland during first two years of exploitation, Proc. of $21^{\text {th }}$ European Photovoltaic Solar Energy Conference, 4-8 September 2006, Dresden, Germany, pp. 3049-3050.

[4] Schwingshackl C., Petitta M., Wagner J.E., Belluardo G., Moser D., Castelli M., Zebisch M., Tetzlaff A.: Wind effect on PV module temperature: Analysis of different techniques for an accurate estimation, Energy Procedia, 40, 2013, pp. 77-86.

[5] Luque A., Hegedus S.: Handbook of Photovoltaic Science and Engineering, Wiley, 2003, pp. 528-541.

[6] Sharmaa V., Sastryb O.S., Kumarb A., Borab B., Chandela S.S: Degradation analysis of a-Si, (HIT) hetro-junction intrinsic thin layer silicon and $\mathrm{m}-\mathrm{C}-\mathrm{Si}$ solar photovoltaic technologies under outdoor conditions, Energy, 72, 2014, pp. 536-546.

[7] Cieślak K., Gułkowski S., Olchowik J.M.: Influence of dielectric coverage on photovoltaic conversion of silicon solar cells obtained by epitaxial lateral overgrowth, Materials Science-Poland, 30, 2012, 274-277.

[8] Luque A., Hegedus S.: Handbook of Photovoltaic Science and Engineering, Wiley 2003. 


\section{THE ROLE OF WIND CONDITIONS IN SOLAR CELLS PERFORMANCE}

\section{S u m m a r y}

Solar modules performance data obtained in STC conditions provided by manufacturers differ from the results obtained from photovoltaic installations working in real external conditions. That is why examination of solar modules performance in different environmental variables such as solar irradiance, temperature and wind speed as well as simulation of their parameters in external conditions is a very significant issue.

The efficiency of solar cells, analogously to other semiconductor devices, depends significantly on the cell operating temperature. Temperature growth causes the increase of electrons energy and narrowing of the semiconductor bandgap. These phenomena result in the changes of $I-V$ characteristic shape where one can observe drop of open circuit voltage and slight increase of short circuit current. Since in real applications of solar cells their efficiency is influenced by environmental variables, experimental observations of the performance of different photovoltaic technologies working in various climate conditions are carried in many scientific centers in the world.

This work focuses on the influence of different ambient conditions, especially wind speed, on the performance of thin film amorphous silicon photovoltaic cells. The analysis based on the theoretical model indicate wind cooling effect at wind speed up to about $10 \mathrm{~m} / \mathrm{s}$. Further increase of wind speed value does not have significant influence on the efficiency of the cells. The characteristic feature of a-Si modules is their good resistivity for temperature changes. This kind of modules can be thus applied in different locations where the weather conditions drastically change from season to season.

Keywords: photovoltaics, amorphous silicon cells, cell efficiency, cell temperature

DOI:10.7862/rb.2016.240

Przestano do redakcji: $30.06 .2016 r$.

Przyjęto do druku: 30.11.2016 r. 